\title{
Successful Treatment with Etanercept of Rheumatoid Arthritis Occurring in a Patient with Familial Mediterranean Fever
}

\section{Ailesel Akdeniz Ateși Olan Bir Hastada Ortaya Çıkan Romatoid Artritin Etanersept Ile Bașarılı Tedavisi}

\author{
Mahmut ALPAYCI ${ }^{1}$, Levent YAZMALAR ${ }^{2}$ \\ ${ }^{1}$ Department of Physical Medicine and Rehabilitation, Bitlis State Hospital, Bitlis, Turkey \\ 2 Department of Physical Medicine and Rehabilitation, Dicle University Faculty of Medicine, Diyarbakır, Turkey
}

\begin{abstract}
Familial Mediterranean fever (FMF) is an inherited disorder characterized by lifelong recurrent, self-limiting attacks of fever and systemic inflammation. Rheumatoid arthritis is an erosive, chronic, inflammatory disease that affects mainly the wrists and joints of the hands. Development of rheumatoid arthritis in a patient with FMF is extremely rare. To our knowledge, this condition has been reported only once previously. Here, we present a 31-year-old female patient who developed rheumatoid arthritis during the course of FMF. In the patient, while the FMF was under control with regular use of colchicine, the rheumatoid arthritis was resistant to conventional therapies. Etanercept treatment provided complete remission in our patient.
\end{abstract}

Key Words: Familial Mediterranean fever, rheumatoid arthritis, etanercept
Özet

Ailesel Akdeniz ateşi (AAA), hayat boyu tekrarlayan ve kendini sınılayan ateş ve sistemik inflamasyon atakları ile karakterize kalıtsal bir hastalıktır. Romatoid artrit ise, çoğunlukla el bileklerini ve eklemlerini etkileyen eroziv, kronik, inflamatuvar bir hastalıktır. Ailesel Akdeniz Ateşi olan bir hastada romatoid artritin gelişmesi oldukça nadirdir. Bildiğimiz kadarıyla, bu durum daha önce sadece bir kez bildirilmiştir. Burada, AAA seyri sırasında romatoid artrit gelişen 31 yaşında bir kadın hastayı sunuyoruz. Hastada, AAA düzenli kolşisin kullanımı ile kontrol altında iken, romatoid artrit ise klasik tedavilere dirençli idi. Etanersept tedavisi hastamızda tam remisyon sağladı.

Anahtar Kelimeler: Ailesel Akdeniz ateşi, romatoid artrit, etanersept

\section{Introduction}

Familial Mediterranean fever (FMF) is an autosomal recessive autoinflammatory disorder characterized by lifelong recurrent, self-limiting attacks of fever and systemic inflammation. The disease is caused by mutations in the MEFV gene, which encodes a protein called pyrin. Pyrin is involved in inflammatory pathways (1). The diagnosis of FMF is based on clinical criteria, and arthritis is one of the minor criteria associated with FMF (2). Articular attacks usually present as monoarthritis, affecting most frequently the large joints of the lower extremities, such as the hip or knee. On the other hand, polyarthritis involving small joints is seen very rarely in the course of FMF (3).

Rheumatoid arthritis (RA) is a chronic, inflammatory, and destructive disease that begins frequently with the involvement of the wrists and small joints of the hands symmetrically. Approximately $1 \%$ of the world's population is afflicted by the disease. This illness frequently affects females between the ages of 30 and 50 (3). The 2010 American College of Rheumatology 
(ACR)/European League Against Rheumatism (EULAR) classification criteria, which are score-based classification criteria, have been developed to facilitate early identification of patients with RA. According to these criteria, a score of $\geq 6 / 10$ is needed for classification of a patient as having definite RA (4).

To our knowledge, development of RA in a patient with FMF has been reported only once previously (3). Here, we present a 31-year-old female patient who developed RA during the course of FMF. In the patient, while the FMF was under control with regular use of colchicine, the RA only responded to etanercept (a TNF- $\alpha$ inhibitor) treatment.

\section{Case Report}

A 31-year-old female patient who had been followed up with the diagnosis of FMF was admitted to our clinic with complaints of pain and swelling in her metacarpophalangeal joints, wrists, and ankles symmetrically. These symptoms were accompanied by morning stiffness, which continued for two hours. Her symptoms had begun about three weeks previously and had become more severe over time. She had been treated with $1.5 \mathrm{mg} /$ day colchicine for approximately five years. The patient was afebrile and did not have abdominal pain; however, she had typical FMF attacks before colchicine use. Also, her three daughters were diagnosed with FMF, too, and they were using colchicine.

Laboratory tests showed hemoglobin $10.4 \mathrm{~g} / \mathrm{dL}$, platelets $467,000 / \mathrm{mm}^{3}$, white blood cells (WBC) $9,000 / \mathrm{mm}^{3}$, fibrinogen 320 , C-reactive protein (CRP) $41.9 \mathrm{mg} / \mathrm{L}$, and erythrocyte sedimentation rate (ESR) $30 \mathrm{~mm} / \mathrm{h}$. Chlamydia antigen, HLA-B27, antinuclear antibody (ANA), and rheumatoid factor (RF) were negative, while anti-cyclic citrullinated peptide (anti-CCP) was positive. Routine biochemical blood and urine tests were normal. Gene analysis revealed an M694V homozygous mutation in her MEFV gene. In hand-wrist $x$-ray images, periarticular osteopenia and soft tissue swelling were detected in the involved regions (Figure 1). Sacroiliac magnetic resonance imaging was normal, and the colon biopsy did not have amyloid deposition.

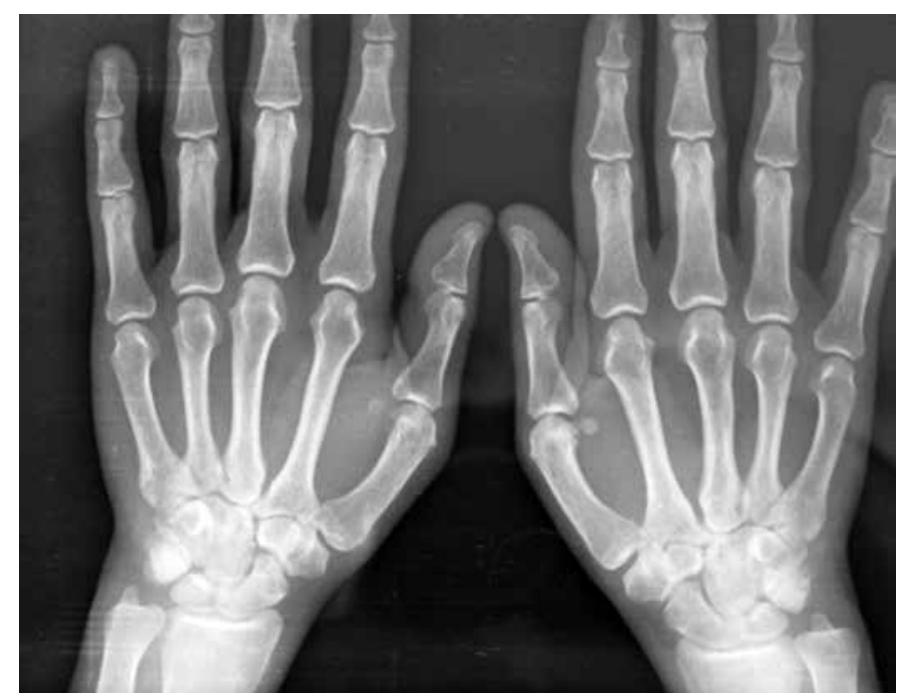

Figure 1. X-ray image of the patient's hands
In light of the present findings, the patient was diagnosed with early-onset RA, and treatment with oral methotrexate 15 $\mathrm{mg} /$ week, prednisolone $10 \mathrm{mg} /$ day, and sulfasalazine $2 \mathrm{~g} /$ day was initiated for RA and treatment with $1.5 \mathrm{mg} /$ day colchicine was continued for FMF. However, for three months, the RA findings did not respond to this treatment (CRP 128, ESR 60). Although leflunomide $20 \mathrm{mg} /$ day and indomethacin $75 \mathrm{mg} /$ day were added to the treatment, the RA did not improve for four months (CRP 115, ESR 76). Thus, all drugs (except colchicine) were stopped and new treatment with etanercept $50 \mathrm{mg} /$ week was started. Following this treatment, at the end of two months, her CRP and ESR levels were normal (4 and 16, respectively) and the RA symptoms were resolved completely. At the end of one year, when the patient discontinued etanercept, her joint pain started again, and RF was low-positive (RF 33.7). Thereupon etanercept treatment was restarted. Informed consent was obtained from the patient for publication of this case report and the accompanying image.

\section{Discussion}

Development of RA in a patient with FMF is very rare, and this condition may lead to confusion in making a differential diagnosis in the presence of polyarthritis. Nevertheless, taking into account the features of both diseases, it can be diagnosed correctly. In addition to the involvement of multiple small joints, as our patient fulfilled regarding the new 2010 ACR/EULAR classification criteria in terms of the presence of anti-CCP positivity and abnormal acute-phase reactants, she was diagnosed as early-onset RA. Moreover, at the clinical follow-up, the duration of symptoms exceeded 30 weeks.

Polyarticular (similar to rheumatoid arthritis) involvement may be seen very rarely in FMF patients (approximately $4 \%$ of the patients). In contrast to RA, attacks of arthritis generally regress in a week without any structural damage (3). But, in about $5 \%$ of FMF patients, protracted attacks of arthritis, particularly involving the hip and knee, can ocur (1). There was no hip or knee arthritis in our patient. Also, because of the presence of anti-CCP positivity and the absence of classical FMF symptoms, such as fever and abdominal pain, we moved away from the diagnosis of FMF arthritis.

There are few studies and contradictory research results in the literature on the relationship between FMF and anti-CCP. While a study (5) has found that anti-CCP antibodies are not associated with FMF, two other studies $(6,7)$ have found that anti-CCP prevalence is higher in FMF patients with arthritis than without arthritis. However, it is still unknown whether there is a relationship between types of arthritis (mono-, poly-, or systemic arthritis) and anti-CCP antibody. On the other hand, several studies have reported the sensitivity of anti-CCP in RA as $41-67 \%$ and its specificity as $90-98 \%$ (7).

In a patient with FMF, if high CRP and ESR levels are found for a long time, it may be a warning for amyloidosis. Our patient's colon biopsy was negative for amyloid deposition. Also, renal function and 24-hour urine protein measures were normal.

Although the coexistence of FMF with rheumatic disorders, such as Behcet's disease, ankylosing spondylitis, juvenile id- 
iopathic arthritis, and RA, has been published before (3), the underlying mechanisms of these overlaps have not been enlightened in full yet. As in our case, these patients had M694V homozygous mutations in their MEFV gene, which encodes the pyrin protein. Mutations of the MEFV gene lead to increased synthesis of pyrin. Pyrin is associated with the interleukin-1-related inflammation cascade and is involved in the regulation of inflammation and innate immunity in patients with FMF (1). Therefore, expressed MEFV mutations in these rheumatic disorders may increase or trigger the inflammatory damage by interleukin-1, which is a key mediator of autoimmune or autoinflammatory diseases (1).

Studies $(8,9)$ have demonstrated that MEFV mutations are accompanied by a more severe course of disease in both FMF and RA. While renal amyloidosis had appeared in the first reported case with these two diseases, our patient was resistant to conventional treatment for RA. We achieved total remission with etanercept treatment in our patient.

As it is known, anti-TNF treatment is effective for both FMF and RA (1). Nevertheless, we continued colchicine treatment with etanercept, because the coexistence of these two autoinflammatory disorders may increase the risk of amyloidosis. Although new evidence reveals a promising role for anti-TNF agents in the treatment of FMF-associated amyloidosis, this protective effect has not yet been proven (1).

\section{Conclusion}

In conclusion, RA may occur rarely during the course of FMF, and this condition may cause confusion in making a differential diagnosis. Coexistence of these diseases can lead to causes of morbidity and mortality, such as amyloidosis and treatment resistance. Etanercept may be an effective treatment option in FMF and/or RA patients with treatment-resistant arthritis.

Informed Consent: Written informed consent was obtained from patient who participated in this case.

Peer-review: Externally peer-reviewed.

Author Contributions: Concept - M.A.; Design - M.A.; Data Collection and/or Processing - M.A.; Analysis and/or Interpretation - M.A.; Literature Review - M.A., L.Y.; Writer - M.A.

Conflict of Interest: No conflict of interest was declared by the authors.
Financial Disclosure: The authors declared that this study has received no financial support.

Hasta Onamı: Yazılı hasta onamı bu olguya katılan hastadan alınmıştır.

Hakem değerlendirmesi: Dış bağımsız.

Yazar Katkıları: Fikir - M.A.; Tasarım - M.A.; Veri toplanması ve/veya işlemesi - M.A.; Analiz ve/veya yorum - M.A.; Literatür taraması - M.A., L.Y.; Yazıyı yazan - M.A.

Çıkar Çatışması: Yazarlar çıkar çatışması bildirmemişlerdir.

Finansal Destek: Yazarlar bu çalışma için finansal destek almadıklarını beyan etmişlerdir.

\section{References}

1. Ozgocmen S, Akgul O. Anti-TNF agents in familial Mediterranean fever: report of three cases and review of the literature. Mod Rheumatol 2011;21:684-90. [CrossRef]

2. Livneh A, Langevitz P, Zemer D, Zaks N, Kees S, Lidar T, et al. Criteria for the diagnosis of familial Mediterranean fever. Arthritis Rheum 1997;40:1879-85. [CrossRef]

3. Turan Y, Şendur OF, Berkit IK. Coexistence of familial Mediterranean fever and rheumatoid arthritis in a case. Turk J Rheumatol 2010;25:44-6. [CrossRef]

4. Aletaha D, Neogi T, Silman AJ, Funovits J, Felson DT, Bingham CO 3rd, et al. 2010 Rheumatoid Arthritis Classification Criteria: an American College ofRheumatology/European League Against Rheumatism collaborative initiative. Arthritis Rheum 2010;62:2569-81. [CrossRef]

5. Karatay S, Yildirim K, Erdal A, Uzkeser H, Erdem FH, Yanmaz V. Anti-cyclic citrullinated peptide antibodies are not associated with familial Mediterranean fever. J Back Musculoskelet Rehabil 2010;23:21-3.

6. Ceri M, Unverdi S, Altay $M$, Ureten $K$, Oztürk MA, Gönen $N$, et al. Anti-cyclic citrullinated peptides positivity rate in patients with familial Mediterranean fever. Clin Exp Rheumatol 2010;28:58-61.

7. Uyanik A, Albayrak F, Uyanik MH, Dursun H, Keles M, Cetinkaya R. Antibodies directed to cyclic citrullinated peptides in familial Mediterranean fever. Rheumatol Int 2010;30:467-71. [CrossRef]

8. Olgun A, Akman S, Kurt I, Tuzun A, Kutluay T. MEFV mutations in familial Mediterranean fever: association of M694V homozygosity with arthritis. Rheumatol Int 2005;25:255-9. [CrossRef]

9. Koca SS, Etem EO, Isik B, Yuce H, Ozgen M, Dag MS, et al. Prevalence and significance of MEFV gene mutations in a cohort of patients with rheumatoid arthritis. Joint Bone Spine 2010;77:32-5. [CrossRef] 